\title{
RELIGIUSITAS DAN STRES PENGASUHAN PADA IBU DENGAN ANAK AUTIS
}

\author{
Ainur Titis Dwi Rahayu', Ni'matuzzahroh ${ }^{2}$, Sofa Amalia ${ }^{3}$ \\ ${ }^{1,2,3}$ Fakultas Psikologi, Universitas Muhammadiyah Malang \\ ${ }^{1}$ ainurtitisdwira0116@gmail.com
}

\begin{abstract}
Abstrak. Seorang ibu yang memiliki anak dengan gangguan autis biasanya mengalami stres pengasuhan yang berasal dari tuntutan perannya sebagai orangtua. Stres pengasuhan akan terjadi dikarenakan kurangnya pemahaman orangtua terkait gangguan anak, sulitnya perilaku anak untuk dikendalikan dan ketidakberfungsiannya interaksi antara ibu dengan anaknya. Sementara itu, religiusitas dapat membantu para ibu untuk mengelola stres yang dialami. Tujuan dari penelitian ini adalah untuk menguji hubungan antara variabel religiusitas dengan stres pengasuhan ibu yang memiliki anak autis. Penelitian ini merupakan penelitian kuantitatif korelasional dengan 60 subjek dan menggunakan teknik quota sampling. Alat ukur yang digunakan untuk mengukur variabel religiusitas adalah skala religiusitas sedangkan variabel stres pengasuhan menggunakan alat ukur parenting stress index (PSI). Teknik analisa data yang digunakan adalah korelasi pearson product moment dengan program spss 21.0. Hasil penelitian ini menunjukkan adanya hubungan negatif antara religiusitas dengan stres pengasuhan dengan nilai signifikasi $<0.05$ dan koefisien korelasi -0.446 .
\end{abstract}

Kata kunci: autis, religiusitas, stres pengasuhan

Abstract. A mother who has a child with autistic disorder usually experience parenting stress from the demands of his role as a parent. Parenting stress will occur due to lack of parental understanding of child-related disorders, the difficulty of the child's behavior to be controlled and non-functioning of the interaction between a mother with her child. Meanwhile, religiosity can help mothers to manage the stress experienced. The purpose of this study was to examine the negative correlation between religiosity variable with parenting stress mothers of children with autism. This research is a quantitative correlation with 60 subjects and using a quota sampling technique. Measuring instrument used to measure the variables religiosity is the religiosity scale Kendler, et al while parenting stress variable using a measuring instrument parenting stress index (PSI). Data analysis technique used is the Pearson product moment correlation with SPSS 21.0 program. The results of this study showed a negative relationship between religiosity and parenting stress the significance value of $<0.05$ and a correlation coefficient of -0446 .

Keywords: autism, religiosity, parenting stress

Beberapa tahun belakangan ini masyarakat semakin familiar terkait pembahasan Anak Berkebutuhan Khusus atau mayoritas masyarakat menyebutnya dengan sebutan ABK. Pembahasan topik ini tidak hanya dalam media online artikel saja melainkan media massa juga banyak mengangkat topik ini. Anak Berkebutuhan Khusus merupakan anak yang memiliki hambatan secara fisik, psikologis, kognitif atau sosial dalam mencapai 
tujuan-tujuan atau kebutuhannya (Mangunsong, 2009). Salah satu jenis gangguan yang mengalami hambatan kognitif dan sosial pada anak berkebutuhan khusus adalah Autis.

Autis merupakan penarikan diri yang ekstrem dari lingkungan sosialnya, gangguan dalam berkomunikasi, serta tingkah laku yang terbatas dan berulang yang muncul sebelum usia 3 tahun (Hallahan \& Kauffman, 2006). Penelitian lain menjelaskan Autis adalah gangguan yang dimulai dan dialami pada masa anak-anak dengan gejala adanya ketidakmampuan untuk berinteraksi dengan orang lain, gangguan berbahasa yang ditunjukkan dengan penguasaan yang tertunda, pembalikan kalimat dan lain sebagainya (Johnson, Burkett, \& Reinhold, 2015). Hal tersebut sesuai dengan karakteristik gangguan Autis itu sendiri.

Mangunsong, (2009) menyebutkan terdapat tiga karakteristik dari gangguan Autis, antara lain gangguan interaksi sosial, gangguan komunikasi dan gangguan perilaku. Selain itu terdapat karakteristik-karakteristik tambahan, yaitu gangguan dalam kognitif, persepsi sensori, motorik, afektif, tingkah laku agresif dan berbahaya serta gangguan tidur dan pola makan (Hallahan \& Kauffman, 2006). Salah satu gangguan yang paling menonjol pada anak Autis adalah gangguan yang berhubungan dengan masalah sosial (Mangunsong, 2009).

Seiring dengan berjalannya waktu jumlah anak autis semakin meningkat di Indonesia, menurut data yang diungkap Kementerian Pemberdayaan Perempuan dan Perlindungan Anak atau yang biasa disebut dengan Kementerian PPA menyebutkan penderita autis di Indonesia pada tahun 2015 diperkirakan mencapai 12.800 anak (Tamba, 2018). Berdasarkan data yang peneliti dapatkan, jumlah anak autis pada sekolah inklusi tingkat SLTA di kota Malang berjumlah 50 siswa yang tersebar ditujuh sekolah. Hallan \& Kauffman (2006) mengindikasi prevalensi sebesar 60 dari 10.000 anak untuk ASD dan 830 dari 10.000 anak untuk Autis saja. Studi secara konsisten menunjukan prevalensi ASD lebih banyak pada anak laki-laki daripada perempuan (3:1 atau 4:1), kecuali pada sindrom Rett, dimana sebagian besar yang terkena adalah perempuan (Hallahan \& Kauffman, 2006). Namun, anak perempuan dengan gangguan autis mempunyai gejala lebih berat dan hasil tes intelegensinya lebih rendah daripada anak laki-laki (Widyawati dalam Mangunsong, 2009).

Berdasarkan data prevalensi yang menunjukan bahwa gangguan autis terus meningkat. Serta permasalahan pada gangguan ini lebih kompleks dibandingkan gangguan perkembangan lainnya, menyebabkan meningkatnya konflik batin orangtua dalam menghadapi anak dengan gangguan autis. Adanya kesenjangan antara harapan setiap orangtua yang ingin memiliki anak yang dapat dibanggakan dengan kenyataan bahwa anaknya mengalami gangguan perkembangan berupa autis, merupakan pemicu adanya konflik atau tekanan batin pada orangtua (Daulay, 2016). Derguy, Bailara, \& Bouvard, (2016) menyebutkan bahwa $70 \%$ orangtua dengan anak autis memiliki tingkat stres pengasuhan yang tinggi. Ludlow, Skelly, \& Rohleder, (2011) mengatakan bahwa tantangan yang dihadapi orangtua dengan anak autis lebih banyak pada permasalahan perilaku, seperti tantrum, repetitif dan agresif. Tantangan lainnya dalam pengasuhan anak autis adalah adanya kesulitan regulasi diri pada diri anak autis sehingga menyebabkan anak memiliki emosi yang negatif (Tomanik dalam Pisula Ewa, 2011). Terdapat gangguan komunikasi juga menjadi tantangan dalam pengasuhan anak autis (Welenski, 2006, dalam Pisula Ewa, 2011). Orangtua dalam hal ini adalah ayah dan ibu. 
Menurut Saragih (Purnomo, 2015) salah seorang pendiri yayasan Nirmala Nugraga, Cilandak, Jakarta Selatan, kedekatan emosional antara orangtua terutama ibu memegang peranan penting bagi kondisi anak autis. Banyaknya beban yang dirasakan oleh ibu sebagai orang terdekat dan yang paling banyak menghabiskan waktu dengan anaknya yang memiliki gangguan autis akan menimbulkan stres pengasuhan. Dengan demikian, menujukkan bahwa peran ibu dalam mengasuh anak autis tidaklah mudah.

Sesuai dengan peneitian Harris \& McHale (Lam \& Mackenzie, 2002) mengatakan bahwa secara psikologis, ibu kehilangan harapan akan anak yang "normal" menerima kenyataan kehilangan kesempurnaan dari anaknya, mengintegrasikan anak kedalam keluarga dan merupakan tanggungjawab ibu yang kekal dalam proses pembesaran anak yang berbeda dari orang lain. Ketidakpastian jangka panjang dari kelangsungan hidup anak, kesehatan dan pertumbuhan anak dimasa depan adalah faktor penambahan tekanan secara psikologis. Hasil penelitian lain menyatakan bahwa tingkat stress pengasuhan seorang ibu lebih tinggi daripada tingkat stres seorang ayah yang memiliki anak autis (Derguy et al., 2016). Hasil data lapang yang diperoleh oleh peneliti pada bulan oktober 2018 menunjukan seorang ibu yang belum mampu menerima kondisi anaknya cenderung menjadikan anak sebagai pelampiasan amarahnya, seperti mencubit, memukul dan mendiamkan anaknya ketika anaknya sulit diatur. Sulit diaturnya perilaku anak ini merupakan salah satu indikator dalam stres pengasuhan.

Stres pengasuhan menurut Abidin, Brunner, Abidin, \& Jack, (1995) adalah suatu tekanan, kecemasan serta tegangan yang melampaui batas secara khusus berhubungan dengan peran orangtua dan interaksi antara orangtua dengan anaknya. Selain itu menurut Deckard (dalam Fitriani, 2013) stres pengasuhan merupakan suatu keadaan yang meliputi aversive psychology dan reaksi fisiologis yang muncul dari usaha untuk beradaptasi atau menyesuaikan diri dengan tuntutan yang ada dalam pengasuhan, dimana stress pengasuhan ini meliputi serangkaian proses. Stres pengasuhan merupakan proses yang mengarah pada reaksi permusuhan psikologis dan fisiologis yang timbul dari upaya untuk beradaptasi dengan tuntutan sebagai orangtua (Henderson, Uecker, \& Stroope, 2016)

Abidin et al., (1995) menyebutkan terdapat tiga aspek stress pengasuhan antara lain aspek pengalaman stres orangtua, dalam hal ini menunjukkan pengalaman stres orang tua dalam pengasuhan anak serta perasaan personal yang timbul setelah kehadiran anak. Selanjutnya aspek perilaku anak yang sulit, hasil wawancara singkat peneliti pada salah satu ibu dengan anak autis yang berada di Malang. Ia mengatakan bahwa dalam proses mengasuh anak autis membutuhkan keikhlasan dan kesabaran ekstra, seringkali mengalami stres ketika anaknya mulai tantrum dan harus mendampingi anaknya sepanjang waktu. Hal ini kerap kali memaksa ibu untuk berhadapan dengan banyak masalah tentang anaknya dan masalah-masalah lain yang ikut membebani pikiran dan perasaanya. Pada aspek ketidakberfungsian interaksi antara orangtua dan anak, dikarenakan kompleksnya gangguan perkembangan anak autis sehingga orangtua khususnya ibu yang lebih banyak memiliki waktu bersama anak kurang memiliki kelekatan emosional dengan anaknya. Hal tersebut yang mempengaruhi perasaan orangtua dan proses pengasuhan anaknya (Abidin et al., 1995). Dengan demikian, menujukkan bahwa peran orangtua khususnya ibu dalam mengasuh anak autis tidaklah mudah, banyak tantangan yang harus dihadapi sehingga dapat menjadi faktor timbulnya stres pengasuhan. 
Derguy et al., (2016) menemukan faktor-faktor yang mempengaruhi stress pengasuhan, antara lain faktor individual atau internal dan faktor lingkungan atau eksternal. Faktor internal meliputi jenis kelamin orangtua, usia orangtua, status pernikahan, jenis kelamin anak dengan gangguan autis dan jenis gangguan autis dari anak. Manning \& Wainwright, (2011) memaparkan bahwa spiritual dapat dikaitkan dengan stres yang lebih rendah. Sedangkan, untuk faktor lingkungan atau eksternal meliputi fungsi keluarga, ekspresi emosi, usia anak saat diagnosis, time since diagnosis, psychoeducational intervention, pendidikan anak, dukungan orang tua dan waktu kerja orang tua. Dukungan sosial telah diidentifikasi sebagai salah satu faktor penting untuk orang tua anak-anak dengan ASD (Bishop, Richler, Cain, \& Lord, 2007). Tipe lain dari dukungan sosial yang digunakan oleh $90 \%$ orang di Amerika Serikat pada saat stres adalah religiusitas atau spiritual (Graham, Furr, \& Flowers, 2001). Penelitian sebelumnya telah menemukan bahwa religiusitas yang kuat meringankan gejala depresi dan kecemasan (Lerman et al., 2018).

Dister (1990) mengartikan religiusitas sebagai keberagamaan karena adanya internalisasi agama kedalam diri seseorang. Monks dkk (dalam Ghufron, 2010) juga memaknai keberagamaan itu sebagai keterdekatan yang lebih tinggi dari manusia kepada Yang Maha Kuasa dimana itu memberikan rasa aman. Semakin manusia mengakui adanya Tuhan dan kekuasaan-Nya, maka akan semakin tinggi tingkat religiusitasnya. Selain itu Mayasari (2014) menyebutkan religiusitas merupakan suatu bentuk hubungan manusia dengan penciptanya melalui ajaran agama yang sudah terinternalisasi dalam diri seseorang dan tercermin dalam sikap dan perilakunya sehari-hari. Studi menemukan bahwa orang sering menggunakan doa sebagai bentuk mengatasi emosi negatif yang berhubungan dengan stres dan perasaan tidak berdaya (Woodrum, 2002). Faciane (2015) menyatakan religiusitas sangat bermanfaat bagi seorang ibu yang memiliki anak autis dari berbagai aspek.

Kendler, Liu, Gardner, Mccullough, Larson, \& Prescott, (2003) mengutarakan terdapat tujuh dimensi religiusitas antara lain, religiusitas umum, religiusitas sosial, keterlibatan Tuhan, sikap memaafkan, Tuhan sebagai penentu, rasa tidak dendam, bersyukur. Keterlibatan agama orang tua tidak hanya membantu mengartikan tantangan pengasuhan dengan kepentingan sehari-hari bagi anak-anak, tetapi juga dengan makna spiritual. Misalnya, mendisiplinkan seorang anak dapat menjadi penting untuk mengajarkan perilaku yang baik, tetapi juga dapat mengambil makna yang lebih besar karena membantu seorang anak "menyerah kepada Tuhan" (Bartkowski \& Ellison, 2009)

Selain dimensi religiusitas, terdapat beberapa faktor yang mempengaruhi religiusitas Thoules (1992) membedakan faktor-faktornya menjadi empat macam, yaitu Pengaruh pendidikan atau pengajaran dan berbagai tekanan sosial. Mahoney, (2010) menunjukkan bahwa agama lebih terkait akan menurunkan stres pengasuhan dan meningkatkan kepuasan orangtua yang lebih besar. Hal ini dikarenakan sebagian besar tradisi agama di Amerika Serikat mempromosikan ideologi kekeluargaan yaitu, kehidupan keluarga adalah sakral dan lebih penting daripada domain kehidupan lainnya. Faktor pengalaman hal ini berkaitan dengan jenis pengalaman manusia yang membentuk sikap keagamaan, faktor kehidupan dan faktor intelektual. Keberfungsian dari religiusitas menurut Faciane (2015) dapat diterapkan pada ibu dari anak-anak dengan ASD dalam mengatasi stres pengasuhan. 
Hasil pelatihan kebersyukuran yang dilakukan oleh peneliti pada bulan oktober 2018 mengungkapkan bahwa ibu yang rajin mengikuti pengajian di sekolah maupun dirumah terlihat begitu sabar dan tenang menghadapi anaknya terutama ketika anak sedang tantrum. Ibu yang rajin mengikuti pengajian ketika anak tantrum lebih memilih memeluk anaknya. Berbeda dengan ibu yang tidak aktif mengikuti pengajian pada saat anak tantrum ibu cenderung ketakutan dan memperlakukan anaknya dengan agresifitas seperti memukul dan mencubit anaknya. Nugrahani, (2015) menungkapkan bahwa stres pengasuhan pada yang dilami orangtua memiliki hubungan yang kuat dengan kecenderungan perilaku kekerasan terhadap anak. Kemudian hasil studi lapang tersebut masuk dalam salah satu dimensi religiusitas menurut Kendler et al., (2003), dimana salah satu dimensinya adalah sosial religiusitas. Bentuk dari sosial religiusitas adalah membina hubungan dengan individu sesama penganut agama dan kehadiran ditempat ibadah. Adanya hasil lapang tersebut dapat membuktikan bahwa religiusitas dapat menjadi salah satu faktor yang berpengaruh dengan stres pengasuhan.

Dister (1990) menyebutkan fungsi dari religiusitas salah satunya adalah untuk mengatasi ketakutan. Ketakutan serta kekhawatiran akan masa depan anaknya menjadi beban pikiran tersendiri bagi seorang ibu yang memiliki anak autis. Hasil studi lapang peneliti disalah satu SDLB Kota Malang, menunjukkan bahwa mayoritas ibu dengan anak autis memiliki ketakutan dan kekhawatiran atas masa depan anaknya. Antonio \& State, (2010) menemukan bahwa pentingnya religiusitas lebih besar berkontribusi terhadap peningkatan kualitas hubungan antara ibu dan anak-anak mereka sementara peningkatan kegiatan bakti dan keyakinan agama di antara anggota keluarga dikaitkan dengan kualitas hubungan yang lebih tinggi di antara semua anggota keluarga. Nilai yang diserap antara lain makna dan tujuan hidup, hati nurani, rasa tanggung jawab dengan Tuhan. Sejauh mana orang tua melihat religiusitas sebagai bagian penting dari kehidupan mereka juga dapat mempengaruhi hasil pada orang tua. Henderson et al., (2016) menunjukkan bahwa religiusitas lebih terkait dengan penurunan stres orangtua dan kepuasan orangtua yang lebih besar. Religiusitas adalah hal yang sangat penting dan lebih banyak bermanfaat untuk pengasuhan dengan cara yang positif. Selain itu, penghayatan dan pelaksanaan terhadap nilai-nilai religius yang komprehensif akan memunculkan perasaan bahagia, senang, puas, merasa aman yang pada akhirnya akan mengacu pada ketenangan batin sehingga mampu menjalankan tuntutan peran sebagai ibu selama proses pengasuhan anak dengan gangguan autis.

Perbedaan peneitian ini dengan peneltian sebelumnya adalah variabel Y dipenelitian ini menggunakan stres pengasuhan sedangkan di penelitian sebelumnya menggunakan variabel stres. Jika dipenelitian sebelumnya menggunakan variabel religiusitas islam dalam penelitian ini menggunakan variabel religiusitas umum. Subjek yang digunakan dalam penelitian stres pengasuhan biasanya adalah pasangan atau ibu dengan memiliki anak berkebutuhan khusus, namun pada penelitian ini subjek yang digunakan lebih spesifik pada ibu yang memiliki anak autis. Peneltian hubungan kedua variabel secara langsung masih belum diteliti di Indonesia.

Berdasarkan rangkaian penjabaran diatas, tujuan dari penelitian ini adalah untuk mengetahui hubungan antara religiusitas dengan stres pengasuhan pada ibu yang memiliki anak autis. Manfaat penelitian ini adalah untuk memberikan gambaran mengenai hubungan religiusitas dengan stres pengasuhan ibu yang memiliki anak autis, sehingga hasil peneltian ini dapat menjadi sumber rujukan peneltian selanjutnya serta 
sebagai salah satu acuan untuk mengadakan program penyuluhan atau psikoedukasi mengenai pentingnya religiusitas pada ibu yang memiliki anak autis.

\section{METODE}

Penelitian ini menggunakan pendekatan kuantitatif. Desain penelitian yang digunakan adalah penelitian korelasional. Penelitian korelasional bertujuan untuk mengetahui tingkat hubungan kedua variabel (Arikunto, 2014). Teknik pengambilan sampel yang digunakan dalam penelitian ini nonprobability sampling, hal ini dikarenakan peneliti tidak mengetahui jumlah secara pasti jumlah populasi ibu yang memiliki anak autis di Kota Malang. Metode pengambilan sampel pada penelitian ini adalah quota sampling, dimana dengan metode ini peneliti menentukan jumlah sampel dari populasi yang memiliki cirri tertentu sampai jumlah kuota yang ditentukan. Jumlah subjek dalam penelitian ini yaitu 60 orang. Kriteria subjek adalah sebagi berikut: ibu yang memiliki anak autis dan rentang usia anak yakni usia sekolah 5-22 tahun.

Pada penelitian ini terdapat dua variabel yakni variabel bebas $(\mathrm{X})$ dan variabel terikat (Y). Adapun yang menjadi varibel bebas (X) (independent variable) adalah religiusitas dan variabel terikat (Y) (dependent variable) yakni stres pengasuhan. Religiusitas yang dimaksudkan dalam penelitian ini adalah perilaku ibu yang memiliki anak autis terkait pemahaman para ibu mengenai penghayatan agama dalam diri ibu kemudian dibuktikan melalui pengabdian seseorang terhadap agama pada kehidupan sehari-hari yang mengacu pada tujuh dimensi religiusitas yaitu general religiosity, sosial religiosity, keterlibatan Tuhan, sikap memaafkan, Tuhan sebagai penentu, rasa tidak dendam, bersyukur. Instrumen penelitian ini menggunakan skala religiusitas Kendler dengan jumlah item sebanyak 29.

Sebelum penelitian dilakukan, kedua instrument tersebut harus melalui validitas konten oleh tiga expert judgemnets dalam bidang perkembangan, keluarga dan psikometri. Validitas isi atau content validity merupakan validitas yang dilakukan dengan pengujian terhadap relevansi item melalui analisis rasional oleh expert judgements. Adapun hasil dari validitas isi yang dilakukan oleh tiga expert judgements pada skala variabel religiusitas.

Pada variabel religiusitas ketiga expert judgement yang sama-sama memberikan nilai relevan terdapat pada item $1,5,8,10,12,17,26$ dan untuk nilai cukup relevan hanya pada item 18, 21. Sisa item yakni item 2, 3, 4, 6, 7, 9, 11, 13, 14, 15, 16, 19, 20, 22, 23, $24,25,27,28$, terdapat dua expert judgement yang memberikan nilai relevan dan satu expert judgement memberikan nilai cukup relevan atau sebaliknya ada beberapa item yang diberikan nilai relevan oleh satu expert judgement dan ada beberapa item yang diberikan nilai cukup relevan oleh dua expert judgement. Terdapat tiga item yang mengalami perbaikan yakni item 16 dan 21, pada item 16 mengalami pengurangan kata yang awalnya "saya yakin bahwa saya harus peduli terhadap oranglain seburuk apapun perlakuan mereka terhadap saya" menjadi "saya harus peduli terhadap oranglain seburuk apapun perlakuan mereka terhadap saya" dan untuk item 21 yang awalnya "saya merasa dinaungi Tuhan setiap hari" menjadi "saya merasa dilindungi Tuhan setiap hari". 
Stres pengasuhan yang dimaksud dalam penelitian ini adalah penilaian ibu yang memiliki anak autis terkait tekanan, kecemasan dan ketegangan berlebihan yang dialami oleh ibu pada saat proses pengasuhan akibat dari berbagai faktor internal maupun eksternal yang mempengaruhi tuntutan peran sebagai orangtua yang mengacu pada tiga aspek stres pengasuhan yakni the parent distress, the difficult child, the parent-child dysfunctional interaction. Stres pengasuhan ini diukur dengan skala PSI (parenting stress index) milik Abidin dengan jumlah item 36.

Pada variabel stres pengasuhan ketiga expert judgement sama-sama memberikan nilai relevan pada item $1,2,3,4,5,6,9,10,11,13,14,15,16,17,18,19,20,21,22,23,24$, $25,26,27,28,29,30,31,32,33,34,35,36$. Pada item 7, 8, 12 terdapat satu expert judgement yang memberikan nilai cukup relevan dan kedua expert judgement memberikan nilai relevan. Pada keseluruhan item tidak terdapat perbaikan bahasa pada setiap item.

Kedua alat ukur dalam penelitian ini menggunakan skala likert yang disusun dengan item yang mendukung konsep (favorable) dan item yang tidak mendukung konsep (unfavorable). Pada setiap item pada kelompok pernyataan tersebut mempunyai lima pilihan jawaban yaitu: Sangat Setuju (SS), Setuju (S), Ragu-ragu (R), Tidak Setuju (TS), Sangat Tidak Setuju (STS). Seacara jelas dirincikan sebagai berikut: sangat setuju pada favorable diberikan nilai 4 dan unfavorable nilai 1, setuju pada favorable diberikan nilai 4 dan unfavorable nilai 2, ragu-ragu pada favorable diberikan nilai 3 begitupun dengan unfavorable, tidak setuju pada favorable diberikan nilai 2 dan unfavorable nilai 4 , dan sangat tidak setuju pada favorable diberikan nilai 1 dan unfavorable nilai 5.

Tabel 1.

Indeks Validitas dan Reliabiltas Instrumen Penelitian

\begin{tabular}{lccc}
\hline \multicolumn{1}{c}{ Alat ukur } & Jumlah item valid & Indeks Validitas & Indeks Reliabilitas \\
\hline Religiusitas & 29 & $0.336-0.775$ & 0.751 \\
Stres Pengasuhan & 34 & $0.337-0.814$ & 0.751 \\
\hline
\end{tabular}

Setelah diuji, maka diperoleh nilai reliabilitas dari instrumen religiusitas adalah 0.751 dimana dari 29 item yang disajikan semuanya dinyatakan valid dengan rentang indeks validitas berkisar antara $0.336-0.775$. Sedangkan untuk instrumen stres pengasuhan diperoleh nilai reliabilitas 0.751 dimana dari 36 item yang disajikan 34 item yang valid dengan indeks validitas berkisar antara $0.337-0.814$.

Penelitian yang akan dilakukan memiliki tiga prosedur utama sebagai berikut: (1) persiapan, tahap persiapan dimulai dari peneliti melakukan pendalaman materi melalui kajian teoritik. Peneliti menterjemahkan dan mengadaptasi alat ukur berdasarkan aspek dalam variabel, selanjutnya peneliti meminta ijin untuk melakukan uji coba. Uji coba dalam penelitian ini menggunakan teknik uji coba terpakai maka hasil uji coba tersebut langsung digunakan untuk menguji hipotesis penelitian. Selanjutnya peneliti melakukan analisa data menggunakan Statistical Package For Social Sciense (SPSS) 21 untuk melakukan uji analisis validitas dan realibilitas item; (2) pelaksanaan, pada tahap pelaksanaan proses pengambilan data berlangsung selama satu bulan yaitu mulai tanggal 3 Januari 2019 - 3 Februari 2019. Peneliti menyebar skala ke Sekolah inklusi dan SLB di kota Malang, diantaranya yaitu : SMKN 2, SMK Tunas Bangsa, SMPN 18, SMPN 12, 
SMPM 2, SMP Sriwedari, SD Plus Qurrota 'ayun, SLB Autis UM, SLB Putra Jaya dan Riverkids. Setelah skala disebarkan pada $60 \mathrm{ibu}$ yang memenuhi persyaratan sesuai dengan karakteristik sampel; (3) terakhir, tahap analisa yaitu menganalisa hasil yang didapatkan dari penyebaran dua skala kepada 60 responden. Data yang diperoleh dianalisa menggunakan Statistical Package For Social Sciense (SPSS) 21. Teknik analisa data yang digunakan adalah korelasi person product moment. Sebelum analisis korelasi dilakukan, peneliti melakukan analisa deskriptif untuk mengetahui gambaran demografis partisipan, selain itu juga untuk mengetahui kategorisasi dari masing-masing variabel. Setelah itu peneliti melakukan uji normalitas data terlebih dahulu untuk mengetahui apakah data yang ada terdistribusi normal atau tidak. Setelah data terdistribusi normal, maka dilakukan analisis korelasi person product moment dan membahas keseluruhan hasil analisa hingga peneliti mampu menarik kesimpulan dari penelitian.

\section{HASIL}

Sebelum analisis hipotesis dilakukan maka perlu dilakukan uji normalitas data terlebih dahulu. Uji normalitas yang digunakan pada penelitian ini adalah uji normalitas skewness kurtosis. Uji normalitas skewness kurtosis dilakukan dengan membandingkan nilai statistik skewness dibagi dengan std. error skewness dan nilai statistik kurtosis dengan std. error kurtosis. Dimana jika skor berada diantara -2 hingga +2 maka data terdistribusi normal. Hasil uji normalitas skewness pada skala stres pengasuhan menunjukan nilai 1.47 dan kurtosis menunjukan nilai 0.49. Sedangkan pada skala religiusitas hasil uji normalitas skewness menunjukan nilai -1.19 dan kurtosis menunjukan nilai -0.15 . Hasil uji normalitas menunjukan nilai berada pada rentang -2 hingga +2 sehingga data terdistribusi normal. Selanjutnya hasil penelitian akan di jabarkan lebih lanjut pada beberapa tabel 3 .

Tabel 2.

Kategorisasi Variabel

\begin{tabular}{lcc}
\hline Variabel Religiusitas & & \\
\hline & $\mathrm{N}$ & Presentase \\
\hline Tinggi & 34 & $57 \%$ \\
Rendah & 26 & $43 \%$ \\
Total & 60 & $100 \%$ \\
\hline Variabel Stres Pengasuhan & & \\
\hline & $\mathrm{N}$ & Presentase \\
\hline Tinggi & 28 & $47 \%$ \\
Rendah & 32 & $53 \%$ \\
Total & 60 & $100 \%$ \\
\hline
\end{tabular}

Tabel 2 pada hasil penelitian menunjukan bahwa untuk variabel religiusitas sejumlah 34 ibu atau 57\% termasuk dalam kategori tinggi, sedangkan 26 ibu sekitar 43\% termasuk dalam kategori rendah. Pada variabel stres pengasuhan menunjukan $53 \%$ atau $32 \mathrm{ibu}$ masuk dalam kategori ringgi dan 28 orang atau sekitar $47 \%$ termasuk dalam kategori rendah. 
Tabel 3.

Distribusi Data Demografi

\begin{tabular}{|c|c|c|c|}
\hline \multicolumn{2}{|c|}{ Karakteristik } & $\mathbf{F}$ & Presentase \\
\hline \multicolumn{4}{|c|}{ Demografi Ibu } \\
\hline \multirow[t]{4}{*}{ Usia } & $<30$ & 3 & $5 \%$ \\
\hline & $30-40$ & 23 & $38 \%$ \\
\hline & $41-50$ & 22 & $37 \%$ \\
\hline & $>50$ & 12 & $20 \%$ \\
\hline \multirow{8}{*}{ Pekerjaan } & Swasta & 14 & $23 \%$ \\
\hline & Ibu Rumah Tangga & 33 & $55 \%$ \\
\hline & Guru & 1 & $2 \%$ \\
\hline & Pedagang & 1 & $2 \%$ \\
\hline & Pensiunan & 1 & $2 \%$ \\
\hline & PNS & 5 & $8 \%$ \\
\hline & Dosen & 1 & $2 \%$ \\
\hline & Tidak Teridentifikasi & 6 & $10 \%$ \\
\hline \multirow{9}{*}{$\begin{array}{l}\text { Pendidikan } \\
\text { Terakhir }\end{array}$} & SD & 2 & $3 \%$ \\
\hline & SMP & 1 & $2 \%$ \\
\hline & SMA & 5 & $8 \%$ \\
\hline & SMK & 5 & $8 \%$ \\
\hline & D3 & 3 & $5 \%$ \\
\hline & $\mathrm{S} 1$ & 13 & $22 \%$ \\
\hline & $\mathrm{S} 2$ & 1 & $2 \%$ \\
\hline & Tidak Teridentifikasi & 30 & $50 \%$ \\
\hline & & raf & \\
\hline \multirow[t]{3}{*}{ Usia Anak } & $5-10$ & 17 & $28 \%$ \\
\hline & $11-18$ & 37 & $62 \%$ \\
\hline & $19-22$ & 6 & $10 \%$ \\
\hline \multirow{2}{*}{ Jenis Kelamin } & Laki-laki & 46 & $77 \%$ \\
\hline & Perempuan & 14 & $23 \%$ \\
\hline
\end{tabular}

Tabel 3 memaparkan bahwa paling banyak ibu yang menjadi responden penelitian ini berusia 30-40 tahun atau 38\%, mayoritas ibu adalah seorang ibu rumah tangga sejumlah 33 atau 55\% dan sejumlah 30 atau 50\% dari responden tidak menyebutkan pendidikan terakhirnya. Sedangkan data demografis anak menunjukan bahwa sejumlah $62 \%$ anak dari responden adalah 11-18 tahun dan 77\% adalah berjenis kelamin laki-laki.

Tabel 4. Uji Korelasi Product Moment

\begin{tabular}{lcccc}
\hline Variabel & $\begin{array}{c}\text { Koefisien Korelasi } \\
(\mathbf{r})\end{array}$ & $\begin{array}{c}\text { Koefisien } \\
\text { Determinasi }\left(\boldsymbol{r}^{2}\right)\end{array}$ & Sig/p \\
\hline $\begin{array}{l}\text { Religiusitas } \\
\text { Stres Pengasuhan }\end{array}$ & $\mathbf{- 0 , 4 4 6}$ & $\mathbf{0 , 1 9 9}$ & $\mathbf{0 , 0 0 0}$ \\
\hline
\end{tabular}

Tabel 4 merupakan hasil uji hipotesis yang menunjukan nilai signifikasi $<0.05$ (sig. 0.000) dan nilai korelasinya yaitu -0.446 yang menunjukan bahwa terdapat hubungan 
yang signifikan antara religiusitas dengan stres pengasuhan pada ibu yang memiliki anak autis. Nilai korelasi tersebut bernilai negatif yang memiliki arti semakin tinggi religiusitas yang dimiliki ibu maka stres pengasuhan ibu rendah. Sebaliknya jika semakin rendah religiusitas maka semakin tinggi stres pengasuhan ibu. Tabel 3 juga menunjukan nilai koefisiensi determinasi $\left(\boldsymbol{r}^{2}\right)$ sebesar 0.199 , artinya adalah kontribusi religiusitas pada stres pengasuhan sebesar $19.9 \%$.

\section{DISKUSI}

Pada penelitian ini bertujuan untuk mengetahui hubungan antara religiusitas dengan stres pengasuhan ibu yang memiliki anak autis. Analisis data menunjukan bahwa terdapat hubungan negatif dan signifikan antara religiusitas dengan stres pengasuhan, dengan nilai signifikan $<0.05$ ( $\operatorname{sig} 0.000<0.5$ ) dan nilai korelasinya -0.446 yang memiliki arti semakin tinggi tingkat religiusitas ibu yang memiliki anak autis maka semakin rendah stres pengasuhan ibu yang memiliki anak autis begitu pula sebaliknya. Kemudian besar nilai kontribusi variabel religiusitas terhadap variabel stres pengasuhan sebesar 0.199 atau sebesar $19.9 \%$.

Hasil penelitian ini tidak sejalan dengan penelitian terdahulu yang dilakukan oleh Cain, (2007), dimana dalam penelitian tersebut ditemukan fakta bahwa religiusitas tidak memiliki pengaruh terhadap stres pengasuhan. Dijelaskan lebih lanjut meskipun stres pengasuhan tidak memiliki pengaruh terhadap stres pengasuhan, namun dalam praktek pengasuhan religiusitas memiliki pengaruh yang positif.

Hasil penelitian ini bisa dijelaskan dengan mengacu pada penelitian yang dilakukan oleh Astri, (2009) mengenai hubungan antara religiusitas dengan stres pada dewasa muda di Indonesia. Astri (2009) juga menemukan adanya korelasi negatif yang signifikan antara kedua variabel tersebut. Berdasarkan perbandingan keduanya, meskipun religiusitas dan stres yang diukur dalam penelitian Astri (2009) tidak terkhusus pada konteks stres pengasuhan seperti dalam penelitian ini. Hasil penelitian keduanya, baik Astri maupun penelitian ini menunjukan hasil berupa korelasi negatif. Oleh sebab itu, peneliti mengasumsikan bahwa hubungan antara religiusitas dan stres tidak hanya berlaku secara umum saja, namun juga secara spesifik pada kehidupan sebagai seorang ibu yang menjalani peran pengasuhan terhadap anak dengan gangguan autis.

Adapun dasar lain yang mendasari adanya hubungan antara religiusitas dengan stres pengasuhan. Dasar yang dimaksud pada hal ini yakni religiusitas dapat membantu individu dalam mengelola stres pengasuhan melalui strategi coping turning back to religion yang diklasifikasikan dalam jenis emotion focused coping yang diteliti oleh Carver \& Scheier, (1989). Penelitian Carver \& Scheier, (1989) memaparkan alasan individu menggunakan religiusitas sebagai sarana coping, hal ini dikarenakan agama dapat menjadi sumber daya emosional individu saat menghadapi hal-hal yang sulit, misalkan individu menjadi lebih sabar dan tabah dalam menghadapi hal-hal sulit dalam kehidupanya. Selain itu Carver \& Scheier, (1989) memaparkan jika strategi coping mampu menjadikan individu memiliki perspektif yang lebih positif dalam memandang sesuatu hal, contohnya ketika individu melihat kondisi sulit yang dihadapinya sebagai suatu proses pengembangan dirinya. Selain itu, adapun konsep religious coping yang didefinisikan oleh Pargament \& Raiya, (2007) sebagai cara yang digunakan untuk 
menghadapi atau menahami kejadian-kejadian negative dengan mengkaitkan pada sesuatu hal yang bersifat sacral atau suci, misalkan seorang ibu yang menghadapi permasalahan dari anak autis lalu mengaitkan permasalahan tersebut sebagai ujian yang diberikan oleh Tuhan dan ujian tersebut harus dijalani dengan sebaik mungkin. Lebih lanjut, Pargament, Koenig, \& Perez, (2000) menjelaskan konsep religious coping mengacu pada fungsi-fungsi agama. Beberapa fungsi dari agama yang dijabarkan oleh Pargament et al., (2000) yakni : berperan dalam pencarian makna hidup dari individu, memberikan kenyamanan saat individu menghadapi hal-hal yang sulit dalam hidupnya, menguatkan kohevisitas sosial dan membantu setiap individu untuk melakukan perubahan atau transformasi dalam hidupnya. Fungsi-fungsi dari agama tersebut dapat diterapkan oleh para ibu dalam menghadapi stres dalam berbagai konteks dalam hidupnya.

Penelitian ini juga menunjukan bahwa untuk variabel stres pengasuhan secara keseluruhan termasuk dalam kategori rendah yaitu sebesar 53\%. Meskipun begitu, variabel ini terdiri dari 3 aspek yaitu the parent distress, the difficult child dan the parentchild dysfunctional interaction. Berdasarkan ketiga aspek tersebut, hasil peneltian ini menunjukkan bahwa aspek the difficult child lebih tinggi dari aspek the parent distress dan parent-child dysfunctional interaction dengan total $44 \%$. Hal ini menunjukan bahwa pada subjek penelitian ini lebih banyak mengalami stres pengasuhan pada aspek the difficult child dibandingkan kedua aspek lainya.

Bentuk aspek the difficult child yang terlihat pada penelitian ini adalah tuntutan anak untuk selalu dibantu dalam semua aktivitas. Bentuk aspek ini terlihat dari total skor pada item nomor 36 yang merupakan skor paling tinggi dibandingkan dengan item lainya. Aspek the difficult child yang tinggi menandakan bahwa masih tingginya stres ibu dalam menghadapi perilaku anak dengan gangguan autis. Hal ini diperkuat oleh penelitian Rahmania, Nunung Nurwati, \& Taftazani, (2016) yang memaparkan bahwa ibu yang memiliki anak autis lebih sedikit untuk memiliki kegiatan bersosialisasi atau kegiatan diluar rumah dibanding dengan ibu dengan anak normal. Sehingga ibu yang memiliki anak autis akan lebih banyak kehilangan waktu untuk dirinya sendiri karena sebagian besar waktunya dipergunakan untuk mengurus anak dan keluarga, hal ini lah yang dapat memunculkan stres.

Subjek penelitian ini melibatkan 60 ibu yang memiliki anak dengan gangguan autis, dari $60 \mathrm{ibu}$ yang menjadi responden penelitian, 34 diantaranya atau sekitar 57\% termasuk dalam kategori memiliki tingkat religiusitas yang tinggi. Aapun dari tujuh dimensi religiusitas, yaitu, general religiousity, social religiousity, forgiveness, god as judge, thanksfulness, unfengefulness, dan involve god, dimensi social religiousity termasuk dimensi yang yang paling tinggi dari keenam dimensi lainya yakni sebesar $22 \%$. Social religiousity adalah merefleksikan tingkat interaksi seseorang dengan individu religius lainnya, selain itu juga menggambarkan frekuensi kehadiran ditempat ibadah (Kendler et al., 2003). Hal ini didukung dengan penelitian Cain (2007) yang memaparkan adanya hubungan positif keluarga yang lebih sering mengikuti kegiatan keagamaan di tempat ibadah dengan praktik pengasuhan, hal ini dikarenakan didalam kegiatan keagamaan para keluarga afrika-amerika selalu mendapat doktrin bahwa keluarga adalah suatu hal yang sakral. Selain itu penelitian Empati, Purnomo, \& Kristiana, (2016) menunjukan bahwa dukungan sosial yang diberikan oleh kerabat keagamaan, keluarga bahkan suami dapat mengurangi stres pengasuhan yang dirasakan oleh para istri. 
Penelitian ini juga memaparkan hubungan antara variabel religiusitas dengan ketiga aspek variabel stres pengasuhan. Seperti pemaparan sebelumnya aspek variabel stres pengasuhan yakni the parent distress, the difficult child dan the parent-child dysfunctional interaction, dari ketiga aspek tersebut, aspek the parent distress menunjukkan tingkat korelasi tertinggi dengan variabel religiusitas dari kedua aspek lainnya dengan nilai korelasi -0.621 dan nilai signifikansi <0.05 (sig. 0.000). Hasil menunjukkan adanya hubungan negatif yang artinya semakin tinggi religiusitas maka semakin rendah aspek The parent distress. The parent distress adalah aspek yang memaparkan mengenai pengalaman stres orangtua dalam proses pengasuhan serta perasaan pribadi yang timbul setelah kelahiran anak, salah satu bentuk perasaan pribadi yakni merasa terisolasi sosial karena tidak mendapatkan dukungan dari kerabat atau suami. Mcstay, Dissanayake, Scheeren, Koot, \& Begeer, (2014) memaparkan pengalaman dan kurangnya pemahaman terkait merawat anak dengan kelainan perkembangan menjadi salah satu pemicu stres pengasuhan. Penelitian Ayun, (2017) memaparkan bahwa individu yang mengalami stres atau tekanan mental yang tinggi membutuhkan aktivitas untuk mengeluarkan tekanan mental tersebut. Lebih lanjut Ayun (2017) coping yang berupa keyakinan beragama pada individu efektif untuk mengurangi tekanan mental atau stres.

Selain itu, penelitian ini juga menunjukan hubungan terkuat pada dimensi variabel religiusitas dengan variabel stres pengasuhan. Pada variabel religisitas terdapat tujuh dimensi yakni dimensi general religiousity, social religiousity, forgiveness, god as judge, thanksfulness, unfengefulness, dan involve god, dari ketujuh dimensi tersebut social religiousity merupakan dimensi yang paling kuat memiliki hubungan dengan variabel stres pengasuhan dengan nilai korelasinya -0.443 dengan signifikansi $<0.05$ (sig. 0.000 ). Hasil korelasi menunjukkan adanya hubungan negatif dimana, semakin tinggi aspek social religiousity maka semakin rendah stres pengasuhan. Ayun (2017) menambahkan bahwa para ibu yang memiliki keyakinan tinggi terhadap agama yang diyakininya dapat merasakan adanya emosi positif untuk bangkit dari kondisi yang menekan, kemudian keyakinan yang dibarengi dengan aktivitas atau ritual terkait keagamaan membuat para ibu memiliki kedekatan kepada Tuhan sehingga menjadikan perasaannya menjadi sabar, ikhlas, penerimaan diri positis serta rasa syukur kepada Tuhan.

Manor \& binyamini, (2017) memaparkan hasil penelitian terkait dengan hubungan negatif antara stres dengan perasaan bahagia, dimana tingkat stres yang tinggi pada orangtua khususnya pada ibu dengan anak disabilitas menimbulkan perasaan bahagia yang rendah pada ibu tersebut. Pertiwi, (2018) mengungkapkan bahwa salah satu yang menjadi faktor kebahagian ibu dengan anak autis adalah agama atau religiusitas. Kebahagian seseorang terkait tingkat religiusitas yang tinggi memiliki pemahaman agama yang baik dan memiliki harapan yang positif akan masa depanya dan mampu menciptakan makna kehidupan yang lebih baik (Seligman, 2005).

Hubungan antar kedua variabel dalam penelitian ini bersifat negatif yang artinya adalah semakin tinggi tingkat religiusitas yang dimiliki ibu maka semakin rendah stres pengasuhan yang dialami ibu dengan anak autis tersebut yang ditandai dengan nilai korelasi -0.446 dan nilai kontribus $\left(\boldsymbol{r}^{2}\right)$ dari variabel $\mathrm{X}$ yaitu religiusitas hanya $19.9 \%$ terhadap variabel Y yaitu stres pengasuhan, sekitar $80.1 \%$ dipengaruhi oleh faktor lain diluar kendali peneliti. 
Banyak faktor yang mempengaruhi stres pengasuhan seseorang, diantaranya adalah self compassion. Stres pengasuhan yang dialami ibu memiliki hubungan negatif dengan self compassion yang dimiliki ibu dengan anak autis, ketika para ibu yang menyayangi diri sendiri disaat-saat sulit, menyadari pikiran dan emosi negatif maka tingkat stres pengasuhan akan menurun (Neff \& Faso, 2014). Stres pengasuhan pada ibu dengan anak disabilitas khususnya autis pada saat menjalankan perannya dalam mengasuh anak juga dipengaruhi oleh beberapa faktor yakni penerimaan orangtua dan dukungan sosial. Stres pengasuhan menurun ketika para ibu dapat menerima kondisi anak sehingga memunculkan kebahagiaan pada para ibu (Perdana \& Dewi, 2017). Dukungan sosial dari kerabat, keluarga dan suami pada saat proses pengasuhan memiliki hubungan yang signifikan dengan penurunan stres pengasuhan yang dirasakan oleh ibu yang memiliki anak autis (Thompson, 2016).

Keterbatasan pada penelitian ini adalah jumlah sampel yang digunakan masih masuk dalam kategori sedikit untuk jenis penelitian kuantitatif yang hanya 60 responden, maka dari itu masih sulit digeneralisasikan. Selain itu, sampel yang digunakan bukan hanya ibu dari anak dengan autis murni melainkan beberapa ibu dengan anak autis kombinasi atau autis dengan gangguan lain. Kemudian beberapa sekolah yang tidak mengizinkan peneliti dalam pengambilan data juga menjadi alasan mengapa jumlah responden dalam kategori sedikit. Sedangkan menurut Azwar, (2007) jenis penelitian kuantitatif apabila semakin banyak sampel yang digunakan maka akan semakin dapat mewakili populasi penelitian.

\section{SIMPULAN DAN IMPLIKASI}

Hasil penelitian ini menujukkan bahwa religiusitas memiliki hubungan yang negatif dan signifikan dengan stres pengasuhan ibu yang memiliki anak autis, artinya semakin tinggi religiusitas ibu maka semakin rendah stres pengasuhan ibu, dengan nilai kontribusi $\left(r^{2}\right)$ variabel religiusitas terhadap variabel stres pengasuhan sebesar $19.9 \%$ dan $80.1 \%$ dipengaruhi oleh faktor-faktor lain diluar kendali peneliti. Implikasi yang dapat diambil dari penelitian ini adalah untuk para ibu yang memiliki anak berkebutuhan khusus, untuk meningkatkan religiusitas pada diri sendiri. Harapanya para ibu mampu untuk menjalankan peran sebagai orangtua serta dapat merawat dan mengasuh anak dengan baik sehingga dapat menurunkan stres pengasuhan yang dirasakan. Salah satu caranya dengan menambah pengetahuan mengenai apa saja yang menjadi kebutuhan khusus anak baik dari membaca buku atau mengikuti pelatihan-pelatihan yang menunjang sehingga nantinya ibu dapat memenuhi kebutuhan anak dengan tepat. Selain menambah pengetahuan, ibu juga dapat mengikuti kajian agama rutin baik datang secara langsung di tempat ibadah, mengikuti kelompok belajar agama atau membaca kitab suci sehingga para ibu dapat lebih menghayati nilai-nilai agama kemudian dalam menjalani proses kehidupan dapat menekan adanya stres berlebihan. Bagi penelitian selanjutnya bisa mencari metode intervensi untuk meningkatkan religiusitas pada ibu yang memiliki anak berkebutuhan khusus sehingga bisa menurunkan stres pengasuhan dari ibu-ibu tersebut.

\section{REFERENSI}

Abidin, R. R., Brunner, J. F., Abidin, R. R., \& Jack, F. (1995). Journal of Clinical Child 
Psychology Development of a parenting alliance inventory Development of a Parenting Alliance Inventory, (April 2015), 37-41. https://doi.org/10.1207/s15374424jccp2401

Antonio, S., \& State, F. (2010). The Couple That Prays Together : Race and Ethnicity, Religion, and Relationship Quality Among Working-Age Adults, 72(August), 963975. https://doi.org/10.1111/j.1741-3737.2010.00742.x

Arikunto, S. (2014). Prosedur Penelitian Suatu Pendekatan Praktik. Jakarta: Rineka Cipta.

Astri, K. (2009). Hubungan antara Stres dan Religiusitas pada Dewasa Muda Beragama Islam. Universitas Indonesia.

Ayun, Q. (2017). Keyakinan (Believe) Beragama Sebagai Coping Pada Individu Yang Mengalami Kondisi Stres. Proceedings International Conference On Indonesian Islam, Education And Science (Iciies) 2017.

Azwar, S. (2007). Metode Penelitian. Yogyakarta: Pustaka Belajar.

Baker, B. L., Blacher, J., \& Olsson, M. B. (2005). Preschool children with and without developmental delay: behaviour problems, parents 'optimism and well-being, 575-590. https://doi.org/10.1111/j.1365-2788.2005.00691.x

Bartkowski, J. P., \& Ellison, C. G. (2009). Discipline and Cherish: Conservative Protestant Perspectives on Children and Parenting. Children and Childhood in American Religions. Edited by Don S. Browning and Bonnie J. Miller-McLemore. New Brunswick: Rutgers University Press, 43-55.

Benson, P. R. (2010). Research in Autism Spectrum Disorders Coping, distress, and well-being in mothers of children with autism, 4, 217-228. https://doi.org/10.1016/j.rasd.2009.09.008

Bishop, S. L., Richler, J., Cain, A. C., \& Lord, C. (2007). Predictors of Perceived Negative Impact in Mothers of Children With Autism Spectrum Disorder, 112(6), $450-461$.

Blacher, J., \& Mcintyre, L. L. (2005). Syndrome specificity and behavioural disorders in young adults with intellectual disability : cultural differences in family impact, (Id), 184-198. https://doi.org/10.1111/j.1365-2788.2005.00768.x

Bowie, J., Soon, H., Tamara, J., Roland, T., Jr, J. T., Ensminger, M., \& Bowie, J. (2017). Predictors of Religiosity in a Cohort of African Americans. Race and Social Problems. https://doi.org/10.1007/s12552-016-9189-2

Boyd, B. A. (2002). Examining the Relationship Between Stress and Lack of Social Support in Mothers of Children with Autism, 17(4), 208-215.

Cain, D. S. (2007). The Effects of Religiousness on Parenting Stress and Practices in the African American Family, 263-272. https://doi.org/10.1606/1044-3894.3624 
Carver, C. S., \& Scheier, M. F. (1989). Assessing Coping Strategies : A Theoretically Based Approach, 56(2), 267-283.

Daulay, N. (2016). Gambaran Ketangguhan Ibu dalam Mengasuh Anak Autis, 1(1), 4974.

Derguy, C., Bailara, K. M., \& Bouvard, G. M. S. R. M. (2016). The Need for an Ecological Approach to Parental Stress in Autism Spectrum Disorders: The Combined Role of Individual and Environmental Factors. Journal of Autism and Developmental Disorders. https://doi.org/10.1007/s10803-016-2719-3

Dister. N. (1990). Pengantar Psikologi Agama. Yogyakarta: Kanisius.

Empati, J., Purnomo, J. C., \& Kristiana, I. F. (2016). Retardasi Mental Ringan Dan Sedang, 5(3), 507-512.

Faciane, K. (2015). The Effect Of Religiosity On Parenting A Child With Austism Spectrum Disorder.

Fitriani, A., Psikologi, F., \& Airlangga, U. (2013). Hubungan antara Hardiness dengan Pengasuhan pada Ibu dengan Anak Autis Tingkat Stres, 2(4).

Ghufron, M. N \& Risnawita, R. S. (2010). Teori-teori Psikologi. Yogyakarta: Ar-Ruzz.

Graham, S., Furr, S., \& Flowers, C. (2001). Research and, 46(October), 2-13.

Hallahan, D. P., \& Kauffman, J. M. (2006). Exceptional learner. Boston, MA: Pearson Education, Inc.

Hastings, R. P., \& Brown, T. (2002). Behavior Problems of Children With Autism , Parental Self-Efficacy, and Mental Health, 107(3), 222-232.

Henderson, W. M., Uecker, J. E., \& Stroope, S. (2016). The Role Of Religion In Parenting Satisfaction And Parenting Stress Among Young Parents, 0, 1-36. Https://Doi.Org/10.1111/Tsq.12147

Johnson, N. L., Burkett, K., \& Reinhold, J. (2015). Translating Research to Practice for Children With Autism Spectrum Disorder: Part I: Definition, Associated Behaviors, Prevalence, Diagnostic Process, and Interventions. Journal of Pediatric Health Care, 1-12. https://doi.org/10.1016/j.pedhc.2015.09.008

Johnston, C., \& Dyer-friedman, J. (2003). Factors Associated with Parenting Stress in Mothers of Children with Fragile X Syndrome, 24(4), 18-22.

Kendler, K. S., Liu, X., Gardner, C. O., Mccullough, M. E., Larson, D., \& Prescott, C. A. (2003). Dimensions of Religiosity and Their Relationship to Lifetime Psychiatric and Substance Use Disorders. Psychiatry, (March), 496-503.

Lam, L.-W., \& Mackenzie, A. E. (2002). Coping with a child with Down syndrome: The experiences of mothers in Hong Kong. Qualitative Health Research, 12(2), 223- 
237.

Lee, E. S., \& Zhang, Y. (2018). Religiosity as a Protective Factor of Psychological Wellbeing among Older Black, White and Asian Christians in the United States.

Lerman, S., Jung, M., Arredondo, E. M., Barnhart, J. M., Cai, J., Casta, F., ... Wassertheil-smoller, S. (2018). Religiosity prevalence and its association with depression and anxiety symptoms among Hispanic / Latino adults, 1-14.

Lestari, S. (2012). Psikologi Keluarga (Penanaman Nilai dan Penanganan Konflik dalam Keluarga). Jakarta: Kharisma Putra Utama.

Ludlow, A., Skelly, C., \& Rohleder, P. (2011). Challenges faced by parents of children diagnosed with autism spectrum disorder. https://doi.org/10.1177/1359105311422955

Mahoney, A. (2010). Religion in families, 1999-2009: A relational spirituality framework. Journal of Marriage and Family, 72(4), 805-827.

Mangunsong, F. (2009). Psikologi dan Pendidikan Anak Berkebutuhan Khusus. Jakarta: LPSP3.

Manning, M. M., \& Wainwright, L. (2011). The Double ABCX Model of Adaptation in Racially Diverse Families with a School-Age Child with Autism, 320-331. https://doi.org/10.1007/s10803-010-1056-1

Manor-binyamini, I. (2017). Ways of coping and mental burnout of Bedouin mothers compared to Bedouin fathers of children with ASD, 7, 61-68.

Mayasari, R. (n.d.). Religiusitas Islam Dan Kebahagiaan (Sebuah Telaah dengan Perspektif Psikologi), 7(2).

Mcstay, R. L., Dissanayake, C., Scheeren, A., Koot, H. M., \& Begeer, S. (2014). Parenting stress and autism: The role of age, autism severity, quality of life and problem behaviour of children and adolescents with autism. https://doi.org/10.1177/1362361313485163

Momtaz, Y. A., Hamid, A. T., Ibrahim, R., Yahaya, N., \& Chai, S. T. (2011). Moderating Effect of Religiosity on the Relationship between Social Isolation and Psychological well-being. Journal of Health, Religion \& Culture, (14), 144-156.

Nashori, F. \& Mucharram, R. d. (2002). Mengembangkan Kreativitas dalam Perspektif Psikologi Islam. Yogyakarta: Menara Kudus.

Neff, K. D., \& Faso, D. J. (2014). Self-Compassion and Well-Being in Parents of Children with Autism. https://doi.org/10.1007/s12671-014-0359-2

Nugrahani, S. (2015). Hubungan Parenting Stres dengan Kecenderungan Perilaku Kekerasan terhadap Anak. Universitas Negeri Semarang. 
Pargament, K. I., Koenig, H. G., \& Perez, L. M. (2000). The Many Methods of Religious Coping : Development and Initial Validation of the RCOPE, 56(4), 519-543.

Pargament, K. I., \& Raiya, H. A. (2007). A DECADE OF RESEARCH ON THE PSYCHOLOGY, 742-766.

Paynter, J., Riley, E., Beamish, W., \& Davies, M. (2013). Research in Autism Spectrum Disorders The double ABCX model of family adaptation in families of a child with an autism spectrum disorder attending an Australian early intervention service. Research in Autism Spectrum Disorders, 7(10), 1183-1195. https://doi.org/10.1016/j.rasd.2013.07.006

Perdana, Gilang Kartika Adi \& Dewi, K. S. (2017). Kebahagiaan Pada Ibu Yang Memiliki Anak Difabel, 4(4), 522-543.

Pertiwi, O. H. (2018). Hubungan Antara Keyakinan Atas Kemampuan Pengasuhan Dengan Kebahagiaan Ibu Dari Anak Autis.

Pisula Ewa. (2011). We are IntechOpen, the world's leading publisher of Open Access books Built by scientists, for scientists TOP $1 \%$.

Purnomo, P. M. (2015). Penerimaan Orang Tua Terhadap Anak Penderita Autis Di Surakarta.

Rahmania, Nunung Nurwati, \& Taftazani, B. M. (2016). Strategi Koping Ibu Dengan Anak Gangguan Spektrum Autisme :

Ramisch, J. (2010). Marriage And Family Therapists Working With Couples Who Have Children With Autism, 1-12. Https://Doi.Org/10.1111/J.1752-0606.2010.00210.X

Seligman. (2005). Authentic Happiness: menciptakan kebahagiaan dengan psikologi positif. Bandung: PT. Mizan Pustaka.

Sugiyono. (2017). No TitlPenelitian Kuantitatif, Kualitatif dan $R$ \& D. Bandung: Alfabeta.

Thoules. R. (1992). Pengantar Psikologi Agama. Jakarta: CV Rajawali.

Wahyuningsih, H. (2008). Religiusitas, spiritualitas, dan kesehatan mental: meta analisis.

Weiss, M. J. (2002). Hardiness and Social Support as Predictors of Stress in Mothers of Typical Children, Children with Autism, and Children with Mental Retardation. https://doi.org/10.1177/1362361302006001009

Winarsunu, T. (2009). Statistik dalam Penelitian Psikologi dan Pendidikan. Malang: UMM Press.

Woodrum, E. (2002). Religious Coping and Church-Based Social Support as Predictors of Mental Health Outcomes : Testing a Conceptual Model, 2, 359-368. 
pISSN: 2301-8267 | eISSN: 2540-8291

Vol. 07, No.02 Agustus 2019 